\title{
Corporate criminal liability on environmental crimes in Vietnam
}

\author{
Thi Mai Dinh ${ }^{1, *}$ Ngoc Thang Dinh ${ }^{2}$, Thi Phuong Quynh Bui ${ }^{2}$, and Anh Duc Nguyen ${ }^{3}$ \\ ${ }^{1}$ Graduate Academy of Social Sciences, Nguyen Trai Street, No. 477, Thanh Xuan District, Ha Noi, \\ 10000, Vietnam \\ ${ }^{2}$ Vinh University, 182 Le Duan Street, Vinh City, 43000, Vietnam \\ ${ }^{3}$ People's Police University, 36 Nguyen Huu Tho Street, District 7, Ho Chi Minh City, 70000, \\ Vietnam
}

\begin{abstract}
From 00:00 on January 1, 2018, all environmental criminal acts of commercial entities are prosecuted for criminal liability. In order to investigate criminal liability for corporate legal entities, up to now, Vietnam have Criminal Code 2015, Criminal Procedure Code 2015 and Law on Execution of Criminal Judgment 2019. However, the competences, order and procedures of judgment excution for corporate legal entities that environmental commit crimes are still controversial and has been urgently discussed. The Penal Code 2015 on corporate legal entities has been in effect for nearly 5 years, but in fact up to July 2020, there has not been a commercial entity prosecuted and tried or excuted yet. The difficult problem is the penalties applied to legal entities different in the nature, order, procedures and ways of conducting compared with individual. This paper introducing the new regulations about the criminal liability on corporate entities for environmental crimes in Vietnam Criminal Code 2015 and analyze and point out some challenges, proposes some suggestions in Vietnam execution of criminal judgments.
\end{abstract}

\section{Introduction}

The Vietnam's new Penal Code 2015 specify 317 crimes of which 12 crimes are environmental ones (accounting for 3.78\%). Also in the 2015 Penal Code's new regulations, for the first time in the legislative history, Vietnam stipulates that corporate legal entities must bear criminal liability within 33 crimes. Remarkably, up to 9 out of the 33 crimes (articles) related to corporate legal entities are environmental crimes (accounting for $27.27 \%$ ). The figure reveals that the criminalization of criminal acts of corporate legal entities in Vietnam mainly focuses on environmental crimes committed by the entities. In addition, Vietnam's new Law on Execution of Criminal Judgment 2019 also adds 10 new provisions on the enforcement of criminal judgments against corporate entities, but the 10 ones also consist of several challenges in the regulations on procedures and competence to enforce criminal sentences against legal entities. This artical, therefore, clarifies 02 major contents:

\footnotetext{
* Corresponding author: dinhthimai@gmail.com
} 
(1). Introducing the new regulations about the criminal liability on corporate entities for environmental crimes in the new Vietnam Penal Code 2015, supplemented in 2017.

(2). Some challenges in law enforcement policy for corporate entities in Vietnam execution of criminal judgments law 2019

\section{Research Methods}

The new Vietnam's Criminal Code was issued in 2015, amended in 2017 and came into force as of January 1, 2018. The Law on Execution of Criminal Judgments was passed in June 2019 and came into effect on January 1, 2020, replacing that of 2010. Until now (June 2020), however, in Vietnam, no environmental criminal cases involving corporate entities have been prosecuted. As a result, in this article, we mainly use the method of studying legal documents without data on specific cases.

\section{Results}

\subsection{Introduction of new provisions on the criminal liability of corporate entities committing environmental crimes in the Vietnam Penal Code amended in 2017}

For the first time in Vietnam's criminal legislative history, the Penal Code 2015 taking effect in 2017 has defined the corporate entities as the subjects of crimes, shown in Chapter XI of the Penal Code, including 16 articles (from Article 74 to Article 89) and in some other specific provisions of the Code (Articles 2, 3, 8, 33, and 46). This is a distinguished and breakthrough innovative point in the criminal policy and criminal legislative thinking in our country, which has sharply changed the traditional perception of crime and punishment. Accordingly, in Chapter XIX of the 2015 Penal Code, there are 12 articles (from Article 235 to Article 246) on environmental crimes, of which 09 articles have supplemented the criminal liability of corporate entities committing the crimes.

Comparing with the 1999 Penal Code, the 2015 Penal Code added the criminal liability of the commercial legal entity into most of environmental crimes in Chapter XIX, including: Crime of causing environmental pollution (Article 235); Crime against regulations on hazardous waste management (Article 236); Crime of breaching regulations on prevention, response, and relief of environmental emergencies (Article 237); Crime of breaching regulations on protection of irrigation works, embankments, and disaster protection works; offences against regulations on protection of river banks (Article 238); Crime of bringing wastes into Vietnam's territory (Article 239); Crime of destroying aquatic resources (Article 242); Crime of destroying forests (Article 243); Crime of breaching regulations on management and protection of endangered, precious and rare animals (Article 244); Crime of breaching regulations on management of wildlife sanctuaries (Article 245); Crime of importing and spreading invasive species (Article 246). Sentences for any juridical entities committing these crimes include fines (primary and additional penalties); suspension of operation; permanent shutdown; prohibition from raising capital; and ban from doing business, ban from operating in certain fields.

The criminal liability supplementation derives from the fact that in recent years, though a number of legal entities and enterprises have committed several acts of causing environmental pollution in a particularly serious a manner, the 1999 Penal Code (amended and supplemented in 2009) did not regulate the criminal liability of the above-mentioned legal entities, so it has been too difficult and ineffective to handle the entities. There have been lots of typical cases such as Vedan Vietnam Company, Ha Tinh Fomosa, Tungkuang 
Company, Miwon Limited Company, Hao Duong Leather Company, Viet Tri Paper Company... with illegal acts causing serious environmental damages (aquatic products, seafood and air pollution), but none of them has been prosecuted criminally. As a result, the fact that the 2015 Penal Code clearly stipulates all corporate entities being the subject of crime conveys a very important significance. The point was clearly shown in details in Chapter XIX:

\subsubsection{Causing environmental pollution (Article 235)}

Over the past time in Vietnam, this crime has been usually committed by the corporate entities. Consequently, the sanctions for this crime for legal entities are quite strict, with the lowest fine of VND 500,000,000 and the highest of VND 10,000,000,000. In the case of causing irreversible consequences, the legal entity will be permanently closed. In addition to the primary penalty, the legal entity may also be liable to a fine of from VND 50,000,000 to VND 500,000,000, ban from doing business, and prohibition from operating in certain fields for one to three years.

\subsubsection{Breaching regulations on prevention, response, and relief of environmental emergencies (Article 237)}

The new penal code added the criminal liability of corporate entities committing the crime with a fine of from VND 1,000,000,000 to VND 10,000,000,000 and being permanently suspended or additional fines of from VND 100,000,000 to VND 500,000,000, prohibited from operating in certain fields for one to three years.

\subsubsection{Breaching regulations on protection of irrigation works, embankments, and disaster protection works; offences against regulations on protection of river banks (Article 238)}

This is a newly added article of the Penal Code 2015. The crime was added aiming to deal with acts of breaching regulations on protection of irrigation works, embankments, and disaster protection works; river banks protection; acts of destroying or damaging irrigation works, embankments, disaster protection works, or works for water resource protection, exploitation, use, monitoring and supervision, or works for prevention, combat and remediation of harmful effects caused by water; and acts of failure to comply with the process and regulations on operation of reservoirs, inter-reservoirs, flood diversion and slowdown works promulgated by competent state agencies, causing serious consequences.

Recent statistics have shown that some hydroelectric facilities in charge of discharging water did not ensure exact time to notify residential areas in the downstream area, which caused flooding and serious damage to the residential areas; the illegal acts drilling, surveying, extracting soil, stones, sand, gravel, minerals, groundwater are quite popular, causing serious landslide consequences for nearby river banks... The crime addition provides deterrent sanctions for the above violations with a fine of up to VND 300,000,000 in Clause 1, up to VND 2,000,000,000 in Clause 2 or face a penalty of from two to ten year imprisonment in Clause 3. The offender might also be liable to a fine of from VND $10,000,000$ to VND $50,000,000$, be prohibited from holding certain positions or doing certain works for two to five years.

If any corporate entities commit this crime, they shall be liable to a fine of from VND $300,000,000$ to VND 5,000,000,000. The violating corporate legal entity might also be liable to a fine of from VND 100,000,000 to VND 500,000,000, prohibited from operating in certain fields for one to three years. 


\subsubsection{Bringing wastes into Vietnam's territory (Article 239)}

One of the important amendments in this article is the provision of criminal liability of corporate entities for the act of bringing wastes into Vietnam's territory. The article states that a corporate legal entity that commits this offence shall be liable to a highest fine of VND 7,000,000,000 or has its operation suspended for six months to three years, or be permanently shut down. The violating corporate legal entity might also be liable to a fine of from VND 100,000,000 to VND 500,000,000, prohibited from operating in certain fields for one to three years.

\subsubsection{Destroying aquatic resources (Article 242)}

The Article has added the criminal liability of corporate entities, stating that a corporate legal entity that commits this offence in any of the cases specified in Clause 1 of this Article shall be liable to a fine of from VND 300,000,000 to VND 1,000,000,000; committing this offence in any of the cases specified in Clause 2 of this Article shall be liable to fine of from VND 1,000,000,000 to VND 3,000,000,000; committing this offence in any of the cases specified in Clause 3 of this Article shall be liable to a fine of from VND $3,000,000,000$ to VND 5,000,000,000 or has its operation suspended for six to three years. The violating corporate legal entity might also be liable to a fine of from VND 50,000,000 to VND $200,000,000$, be prohibited from operating in certain fields or raising capital for one to three years.

\subsubsection{Destroying forests (Article 243)}

The law added the criminal liability of corporate entities for this crime with the sanctions for criminals are: fines with the lowest amount of VND 500,000,000 and the highest of VND 7,000,000,000; having their operations suspended for six months to three years; or being permanently shut down. The violating corporate entities might also be liable to a fine of from VND 50,000,000 to VND 200,000,000, be prohibited from operating in certain fields or raising capital for one to three years.

\subsubsection{Violating the regulations on management and protection of endangered, rare animals (Article 244)}

The Article added the criminal liability of corporate entities with the primary penalty of a fine of from VND 1,000,000,000 to VND 15,000,000,000; suspended operation for six months to three years or permanently suspended operation. The violating corporate legal entity might also be liable to a fine of from VND 300,000,000 to VND 600,000,000, be prohibited from operating in certain fields or raising capital for one to three years.

\subsubsection{Violating regulations on the management of natural reserves (Article 245)}

The article supplements the criminal liability of corporate entities with a fine of from VND $300,000,000$ to VND 3,000,000,000, suspended operation for six months to three years or permanently suspended operation. The violating corporate legal entity might also be liable to a fine of from VND 50,000,000 to VND 500,000,000, be prohibited from operating in certain fields or raising capital for one to three years. 


\subsubsection{Importing, spreading invasive species (Article 246)}

The law also adds the criminal liability of corporate entities with a fine of from VND $1,000,000,000$ to VND 5,000,000,000, suspended operation for six months to three years. The violating corporate legal entity might also be liable to a fine of from VND 100,000,000 to VND $1,000,000,000$, be prohibited from operating in certain fields or raising capital for one to three years.

It has been obvious that a most of very serious and particularly serious environmental consequences in Vietnam were not caused by just one or two individuals but a group of people such as the Management Council; illegal benefits did not go to any individuals but to enterprises or economic organizations. Besides, in many cases with particularly serious physical and mental damages caused by corporate entities, the victims' interests are surely not protected if only individual offenders are prosecuted. The above mentioned fact raises the need to apply stricter sanctions to combat this dangerous crime and to ensure equality in the crime handling policy. As a result, the additional provision of the criminal liability of corporate entities in the 2015 Penal Code is an important innovation to meet the domestic practical requirements as well as to affirm the robust current trend of international integration of law and justice in Vietnam.

\subsection{Some challenges in the policy on execution of criminal judgments for legal entities specified in the law on execution of criminal judgments 2019}

Following the addition of new provisions of the 2015 Penal Code on corporate entities being the subjects of the crime, the Law on Execution of Criminal Judgments 2019 has added a new chapter, namely Chapter XI: Execution of judgments against corporate entities, including 10 articles (from Article 158 to Article 167). However, these provisions have revealed a number of new and challenges reflected in the regulations on the principles, subjects, authorities, procedures and legal consequences of execution against corporate entities committing crimes. The following analysis will analyze the new points and point out some challenges in the new regulations, as well as propose some recommendations and solutions of principle and approach at the policy level.

\subsubsection{New regulations on subjects with competence and obligation to execute criminal judgments against corporate entities committing crimes}

Chapter XI specifically defines and distinguishes two types of subjects (two types of agencies), including:

- The subjects/agencies assigned to execute criminal judgments against corporate entities committing crimes (the subjects/agencies with criminal judgement execution competence) in Article 158.

- The subjects/agencies with obligations and responsibilities in criminal judgment execution against corporate entities committing crimes (the subjects/agencies with obligations) in Article 164: Responsibilities of state management agencies corporate entities.

Article 158 of the Law on Execution of Criminal Judgments 2019 (The Law on Execution of Criminal Judgments 2019) stipulates that "the agencies assigned to execute criminal judgments" consisting of only three types: Competent and assigned agencies to execute criminal judgments against corporate entities include: Criminal judgment execution agencies of provincial-level police departments; Criminal judgment execution agencies of military zones; and Civil enforcement agencies.

Specifically: 
- "1. Criminal judgment execution agencies of provincial-level police departments and of military zones shall execute penalties and judicial measures as prescribed in Articles 78, 79, 80, 81 and Point b, Point c Clause 1 Article 82 of the Criminal Code in accordance with this Law". (Clause 1, Article 158)

- "2. Civil enforcement agencies shall collect fines as prescribed in Article 77 and enforce judicial measures as prescribed in Point a Clause 1 Article 82 of the Criminal Code in accordance with law on civil judgment enforcement." (Clause 2, Article 258).

Looking back at the regulations in the previous drafts, it is popularly understood that there must be a close coordination between the agencies in charge of criminal judgment execution (the Criminal judgment execution agencies of provincial-level police departments and of military zones) with the state management agencies with expertise in specialized fields related to the corporate entities' operations (corporate entities) such as Business License agencies who can legally allow corporate entities to operate, including: Business Registration Offices under the Department of Planning and Investment of centrallyaffiliated cities and provinces...; with the state management agencies directly related to the execution of penalties or judicial measures against corporate entities such as: State management agency on environment; Customs Agency; Ranger Agency; Market Management Agency...; or with Credit institutions and funds with direct investment who are directly involved in the enforcement of a ban on capital mobilization against corporate entities, etc.

Currently, the article 164 of Law on execution of criminal judgments determines that the state management agencies for corporate entities are not the subjects with the judgement enforcement, but with the obligation to execute judgments. The article 164 also does not name or specify which state management bodies for corporate legal entity, instead, it specifies the responsibilities and measures that these agencies must carry out, including five measures specified from the Point a to Point đ of Clause 1; and four other required activities (from Clause 2 to Clause 5, Article 164).

The above mentioned provisions have been considered relatively reasonable, however, regarding the subjects with competence to execute judgments against corporate entities, we recommend:

- Firstly, it is necessary to add the subjects "state management agencies for corporate entities" as the ones with competence to execute judgments, not just the obligation or "coordination" ones to execute criminal judgments against corporate entities.

In our opinion, the most problematic and difficult problem in both theory and practice in criminal judgment execution against corporate entities lies in the characteristics of the subjects of legal corporate entities bearing the criminal judgments which are fundamentally different from the subjects of individuals (specific person). Besides, the penalties applied to corporate entities are also different in nature, order, procedures and manner of proceeding compared to individuals. For individual offenders, penalties (e.g., life imprisonment, term imprisonment or ban from holding positions, prohibition from operating in certain fields, or deportation...etc...) will be imposed and enforced by the criminal judgment agencies. For offenders as corporate entities, in principle, the penalties are also applied and enforced by the judgment enforcement agencies. However, when imposing penalties (for example, a ban on trading, or prohibition of capital raising or permanent shutdown, or a definite suspension of operations in some sectors) against a corporate legal entity, the questions will be: Which measures and procedures should criminal judgment execution agencies of provincial-level police departments and of military zones apply to prohibit/suspend its operations? Evidently, it is impossible to prohibit and suspend the entity's operations by the same method of physical nature such as a measure of "holding in a detention facility" as the one imposed on an individual offender.

- Secondly, it is necessary to add in Article 158 the subject "Civil enforcement agency" 
as an entity in the system of criminal judgment execution agencies because the agency is assigned a number of criminal judgment execution tasks.

As we can see, in Article 11 of the Law on Execution of Criminal Judgements 2019, the system of execution of criminal judgment organizations does not stipulate that the Civil enforcement agency is a subject assigned criminal judgment execution tasks, while in reality and in Clause 2, Article 158 affirms that fines (as a primary and additional penalty) to corporate entities (and also to individual offenders) are "assigned to the civil enforcement agency for execution".

\subsubsection{New provisions on procedures for execution of sentence against corporate entities committing crimes}

Sentences are the most influencing factor on measures, procedures, and ways of organizing the criminal judgement execution against corporate entities. Under the 2015 Penal Code, penalties for commercial legal criminals include:

- Four primary sentences:

+ Fine (Article 77),

+ Suspension of operations in one or some fields (Article 78),

+ Permanent shutdown in one or some fields (Article 79, Clause 1),

+ Permanent shutdown in all operations (Article 79 Clause 2).

- Three additional penalties:

+ Prohibition from operating in certain fields (Article 80)

+ Prohibition from raising capital in the forms of: a) Prohibition from taking loans from banks, credit institutions, and investment funds; b) Prohibition from issuance and securities offering; c) Prohibition from raising capital from clients; d) Prohibition from cooperation and association both in Vietnam and overseas; đ) Prohibition from establishing real estate trusts. (Article 81).

+ Fine (when not applied as a primary penalty)

- Four judicial measures:

+ Confiscation of money and items directly related to the crime (Article 82, Clause 1);

+ Return, repair of property or provision of compensation; offering of public apology (Article 82, Clause 1, Point a);

+ Compulsory restoration of original state (Article 82, Clause 1, Point b)

+ Compulsory implementation of some measures for mitigation and prevention of consequences (Article 82, Clause 1, Point c). The measures include: a) Compulsory dismantlement of the work or part of the work that is not licensed or built against the license; b) Compulsory relief of environmental pollution or spread of disease; c) Compulsory removal from Vietnam's territory or re-export of goods, vehicles taken into Vietnam's territory against regulations of law, or those temporarily imported but have not been re-exported as prescribed by law; imported or transited goods that infringe intellectual property rights; counterfeit goods; vehicles, raw materials imported for manufacture or trading of counterfeit goods after the elements of violation have been removed; d) Compulsory destruction of goods or items that harm health of humans, animals, plants, and the environment; obscene materials or other exhibits subject to destruction as prescribed by law; đ) Compulsory removal of violation elements on the goods, goods labels, means of trading, or items; e) Compulsory recall of violating products being sold on the market. (Article 82, Clause 3)

Thus, apart from fines, the primary and additional penalties applied to corporate entities consist of a common characteristic that limits their rights to perform one or some, or all business activities.

Besides, the execution order and procedures of fine penalty shall be determined and 
executed by a Civil enforcement agency in accordance with the Law on Execution of Civil Judgments.

The three other primary sentences and the three other additional penalties analyzed above have the same nature of monitoring or "banning", "suspending" effect of one, some or all business activities of corporate entities committing crimes.

However, the provisions on measures and procedures for the execution of the six sentences for corporate entities as in the Law on Execution of Criminal Judgements 2019 still contains some shortcomings.

As a result, we recommend following issues:

We recommend the following issues:

First of all, while there are still no specific regulations on the order, procedures and conditions for corporate entities to voluntarily execute their criminal judgments, the "hard" provisions on compulsory procedures that criminal judgment execution agencies must "carry out the following procedures" as defined in Clause 2, "Article 160 of Procedures for execution of sentence", including summoning representatives, announcing execution decisions, and issuing enforcement decisions... are unreasonable. For example, if a corporate legal entity voluntarily executes its criminal judgment, the summoning and making of an enforcement decision get counter-productive.

Secondly, the new law only stipulates and envisages "one-way". It means that when step 1 is done, what step 2 will be and the last step will be a certificate of sentence completion, etc. On the contrary, if the legal representative of the corporate legal entity does not appear without plausible reasons (very commonly), or deliberately avoids completing its criminal sentence(s), there are still no effective handling measures to force the corporate legal entity to implement all steps in the criminal judgment execution.

\subsubsection{Challenges in the provisions on the subjects of state management and their responsibilities in the performance of joint obligations in the execution of criminal sentences against corporate entities}

Two major challenges are identified:

- The first: The new Law on Criminal Judgment Execution 2019 has not regulated and classified the subjects as state management agencies for corporate entities.

- The second: The new Law on Criminal Judgment Execution 2019 has not included provisions on the responsibilities and obligations of the subjects as state management agencies in performing joint obligations in criminal judgment execution against corporate entities.

One of the vital issues of judgment enforcement against corporate entities is to determine which are state management agencies in judgment execution against corporate entities? Who or which agencies have authority and are able to enforce the penalties imposed on corporate entities committing crimes?

Corporate entities as subjects to criminal judgment execution include two main groups: businesses and other economic organizations. Regarding the nature of the entities' transaction activities, it is possible to classify their operations into three main groups, namely: "operating itself", "operating with the public entities", and "operating with private entities" group.[6]

As a result, it is possible to determine the subjects as well as the order and procedures of criminal judgment execution against corporate entities committing crimes based on the two categories. On the other hand, we can identify the ways to execute criminal judgements on the ground of sentence types.

However, to determine which agencies are state management ones with related responsibilities, rights and obligations in criminal judgment enforcement against criminal 
corporate entities as well as to propose the suitable execution order and procedures for each executor, from our initial research, the most reasonable way should not be dependent on the punishment, but the subjects being executed (considering if the corporate legal entity bearing criminal judgment execution is a business or an economic organization).[7]

We, therefore, propose that the determination of the State management agencies in criminal judgment execution against corporate entities and the enforcement order and procedures must be determined and classified based on the business characteristics of the entities, as in the following 3 specific groups:

Group 1: Group of state management agencies in criminal judgment execution against corporate entities in industries and occupations that do not require business conditions and administrative procedures (a legal entity only needs to register for an enterprise to operate.)

Corporate entities are allowed to enterprise in all industries and trades that are not prohibited by law (freedom of business). For this type of commercial legal entities, the primary competence to monitor, supervise and enforce criminal judgments belongs to the business management agencies which are business registration agencies at all levels and tax authorities.

Thus, the state management agency in criminal judgment execution against corporate entities operating in industries and trades without business conditions and administrative procedures is the Ministry of Planning and Investment, the Department of Planning and Investment (at all levels) and the Tax Department.

Currently, an automatic electronic inter-agency coordination mechanism between business registration agencies and tax authorities is done through the process of creating and using enterprise identification numbers. The Department of Planning and Investment is the focal point to publicize information about enterprises and its affiliated units violating the Law on Investment and Law on Enterprises. The Tax Department publishes a list of enterprises and its affiliated units in their localities violating the Tax law. The form of publishing information on handling of enterprises committing crimes of each agency is done on its own web portal according to the process of publishing electronic information.

Group 2: Group of state management agencies in judgment execution against corporate entities in the sectors and trades subject to conditional business investment

For sectors and trades under conditional business investment (including 243 industries and trades as prescribed by the Law on Investment), legal entities wishing to operate must have a certificate of business eligibility, or a license to operate (called pre-check.) [6]

The State management agencies in criminal judgment execution against corporate entities dealing in conditional industries or trades are State management agencies assigned to assume the prime responsibility for state management for sectors and trades subject to conditional business investment, or the State agency that directly carries out administrative procedures (pre-check) in accordance with the law (The one with authority to issue, revoke, or modify the certificates of eligibility, or equivalent documents, to the corporate entities. For example: The Securities Commission for legal securities businesses, State Bank - for banking credit institutions). [6]

However, not all of these 243 sectors and trades have the same results of state management as a type of business qualification certificate, business license ... (ie. State management by the pre-check method). Under the general direction of the Government, many of the 243 the sectors and trades are gradually changed from bearing pre-control to post-check management, meaning that the business will only be controlled during its operation through state inspection and check, not be necessarily checked and licensed before operating.[4, 47]

As a result, for sectors and trades bearing state management on business conditions under the post-check regime, in reality, the implementation of penalties (business prohibition, operating prohibition...) is performed in the same way as business entities 
without conditional business investment.

Group 3: Group of state management agencies in judgment execution against the corporate entities who must complete enough administrative procedures before carrying out their business activities (licenses, practice certificates and equivalent documents)

According to Article 8, Clause 2, Point a, Decree 92/2017 on the control of administrative procedures, the administrative procedures are implemented by the following methods:

- The corporate legal entity requests a competent management agency to issue permits, approve, certify ... before its operation. (administrative - pre-check)

- The corporate legal entity registers with the competent State management agencies to operate. However, the registration may need an agreement response (to operate) or no responses (after a certain time without any responses, the enterprise automatically has right to operate).

- The corporate legal entity informs its activities to relevant State management agencies without waiting for their agreement response (administrative - post-check). For this third form only, the administrative procedures are carried out according to the post-check regime so that the implementation of measures to prohibit business and prohibit activities is quite similar to that of legal entities without business conditions (belong to group 1).

As we can see, the two above subjects are enabled to start-up with the post-check administrative procedures, whereas for the two others with the pre-check administrative form, State management agencies in criminal judgment execution against corporate entities with conditional business are the ones that directly perform administrative procedures in accordance with law. [2]

For example:

- State management agencies in criminal judgment execution against corporate entities with conditional business are Customs authorities, shipping companies, airport authorities, customs agents... when they carry out the prohibition/suspension sentences of import and export activities;

- or: They are State Bank, airport authorities, insurance enterprises, securities company... when executing a suspension sentence of financial transactions to corporate entities committing crimes.

\subsubsection{No regulations on the form and measures of criminal judgment execution against criminal corporate entities}

The provisions in the Law on Execution of Criminal Judgments 2019 have not yet answered the question: How are the criminal judgments executed against the corporate entities? With what specific manners and measures?

The forms and measures to enforce criminal judgments against corporate entities are a new issue so that they have not been studied both in the practice and theory of the law policy on criminal judgment execution. On these days and age, they have become a controversial matter and in fact, there have been cases related to corporate entities being prosecuted. Unfortunately, there are still no first-instance convicts nor their implementation in reality which may enable us to check if there are any specific challenges when applying the new provisions in practice. However, it is the duty of researchers and policy-makers as well as practical law-applying activists to study and foresee the situation. Through research, we suppose that:

\subsubsection{Firstly, it is necessary to provide additional provisions on the form of criminal judgment execution against corporate entities}


We believe that it urgent to supplement the article to regulate the criminal judgment execution measures against corporate entities.

In details, there should be the provisions on two main measures in the execution of sentences against corporate entities, namely: Voluntary execution and Coercive judgement execution. In the form of voluntary execution, it is necessary to work out the regulation or specific guidance of the deadline for a corporate legal entity to voluntarily execute its criminal judgment(s). When the deadline expires, if the execution is not voluntarily implemented, the compulsory enforcement measure shall be applied.

In principle, there are two main forms of criminal judgment execution against corporate entities, including:

- Voluntary execution: Immediately after the judgment takes legal effect, the criminal corporate legal entity is obliged to abide the judgment as well as the judgment execution decisions of the judgment enforcement agency and State management agencies related to the criminal judgment execution.

- Coercive judgement execution: In cases where the corporate legal entity does not voluntarily or incompletely execute the judgment, the compulsory execution shall be applied. Unfortunately, coercive measures are not specified in Article 163 of coercive judgment execution nor in other articles.

Previously, according to the draft Law on Execution of Criminal Judgments, amended and supplemented in 2018 (the 6th, Article 178), the coercive measures included:

+ Forcible immediate termination of activities which have been suspended or banned by the Court;

+ Forcible public information on activities suspended or banned by the Court on public media according to law provisions;

+ Sealing, temporarily seizing documents, vouchers, electronic data, the legal seal(s) of the corporate legal entity;

+ Blocking bank accounts;

+ Distraining property.

These options are also a valuable reference which need more researches for the Government to have specific implementation guidance.

\subsubsection{It is necessary to study to supplement specific provisions on criminal judgment execution measures against corporate entities}

The judgment execution measures for corporate entities are problematic because of the "non-natural person" characteristic of the corporate legal entity. The execution of criminal judgments against corporate entities is, therefore, completely different in the nature and enforcement measures when comparing with that against individual offenders.

As analyzed above, penalties (primary and additional ones) applied to corporate entities, only the fine is assigned to the civil judgment enforcement agency to comply with the provisions of the Civil Procedural Law (currently can be easily implemented with no challenges). However, the other sentences consist of one common characteristic of restricting the right to perform one or some, or all of the enterprise's activities. [1]

Thus, regarding the feature, we have worked out two specific characteristics that determine the criminal judgment enforcement measures against corporate entities, namely: - First, the corporate legal entity itself does not perform the act (transaction) without a representative.

- Second, the corporate legal entity activities are formed by: the representative's acts and the partner's ones.[6]

Consequently, when imposing a penalty on a corporate entity, we should ensure that the penalty has real influence on the representative's acts or the partner's ones (or both) to 
suspend, temporarily suspend, prohibit, or permanently ban one (or some, all) activities (or sectors) of the corporate legal entity committing crimes.

Besides, in order to determine the method, subject, and the criminal judgment execution order and procedures against a corporate legal entity, we should base on the characteristics and nature of the corporate legal entity's activities.

Our research has shown that it is possible to classify legal entities' activities into three groups, including:

- Group 1, "self-operating": All activities are done by the corporate entities themselves without coordination or transaction with any second entities, such as: machine operation, self-production, processing, business management activities ...

- Group 2, “operating with public entities": The corporate legal entity's activities are done with transactions with state agencies.

- Group 3, "operating with private entities": The corporate legal entity's activities are done with transactions private entities (such as trading goods, providing services, hiring labor, transferring property ownership...etc...)

For the type of the corporate legal entity's activities in Group 1, we name it "selfoperating". These are physical activities taking place at the manufactories (manufacturing, transporting, building, operating, operating ... the enterprise) so that the determination of judgment execution responsibility entirely belongs to the specialized criminal judgment enforcement agency (imposing suitable measures to monitor/prohibit/suspend these activities at the basements). For example, if the producing process must be suspended, the judgment enforcement agency will seal up the machinery and the factory and appoint a supervisor.[3]

For group 2: "operating with public entities". This group have transactions with state agencies, so the specialized criminal judgment enforcement agency needs to send a notice to the corresponding state agencies (that the group enterprise has or will have transactions) to request them to stop, suspend, or permanently suspend their operations with the corporate entities under the applied penalties. For example: If an enterprise has to execute the penalty of being prohibited to trade or issue securities, the judgment enforcement agency has to require the State Securities Commission to ban these activities of the enterprise.

The third group, "operating with private entities" is considered the most complicated in the criminal judgment execution activity against corporate entities. Because the corporate legal entity performs transactions with the second party as a private subject (with other individuals, legal entities, with an unjust subject), the judgment enforcement agency, on the one hand, requires the enterprise to voluntarily carry out its penalty. On the other hand, the agency should have a form of public notification to private entities (and to the public) with the content: All transactions made by the convicted corporate legal entity within the prohibited/ suspended fields (according to the judgment) are considered invalid. If any individuals or corporate entities still tries to make transactions (within the prohibited/ suspended fields) can be punished for administrative violations according to the law. [4]

In a nutshell, the determination of the appropriate form and measures of criminal judgment execution should be based on the characteristics of the corporate.

Note that:

- When executing penalties related to the "self-operating" of the corporate entities, criminal judgment execution agencies of provincial-level police departments and of military zones should be given priority to apply the supervision measures for "physical" activities such as production, transportation, construction, management, administration, and operations at the office of the corporate legal entity subject to judgment execution.

- When executing penalties related to the "operating with public entities" of the corporate entities, it is advisable to assign and coordinate closely with state management agencies in 
charge of state management in sectors and trades with conditional business investment (for corporate entities doing conditional business). At the same time, the state agencies directly implementing administrative procedures (for corporate entities with "pre-check" procedure) should be assigned to pause/restrict/deny/prohibit/suspend or control the activities according to the relevant punishment levels declared against the entity.

- When executing penalties related to the "operating with private entities" of the corporate entities, it is necessary to adopt appropriate and flexible coordination, monitoring and control mechanisms. For example: Requiring the legal entity to report; the state management agency refusing all related transactions; or widely warning private entities to stop all prohibited transactions. If the transaction continues to be made, it is considered void and the entity may be liable to law sanctions.

\subsubsection{No regulations on the principles of criminal judgment execution against corporate entities committing crimes}

Although Article 4, the Law on Execution of Criminal Judgements 2019 has specifically stipulated eight principles of criminal judgment execution, we assume that these principles have only been studied based on the policy of criminal judgment execution applied to individual offenders. The corporate entities have not been intensively studied, so there have been no "policy level" principles in the execution of criminal sentences against corporate entities.

Consequently, the issue needs sufficient and longtime researches. However, with the initial study outlines, we believe that the principles of execution of corporate entities committing crimes should cover the aspects with large impact on economics, politics, including:

- Firstly, the execution of criminal judgments against corporate entities not only affects the legal entities themselves, but also employees, individuals and organizations with related interests.

- Secondly, it is necessary to consider and carefully calculate the legal consequences of the judgment execution against the corporate entities committing crimes. As we know, their activities are related to many factors such as: financial obligations to the state, the creditors' interests to the legal entity, especially the employees' benefits, occupations, social insurance, and health insurance... These entities are innocent though they are parts of the corporate entities.

- Thirdly, the negative effects of penalties imposed on corporate the corporate entities with large scale of operations and employees will greatly affect the workers' lives, even cause social disorder and safety and other negative and unstable consequences for society.

- Fourthly, attention should be paid to deal with legal consequences after the criminal judgement execution, especially with creditors and employees' interests... under the Law on Bankruptcy applied to the corporate entities subject to the sentence of permanent suspension (death penalty). Accordingly, it is necessary to consider arising issues including: bankruptcy cost; salary debts, severance pay, employees' social insurance, health insurance, other benefits under the labor contract and the signed collective labor agreement; debts arising after the opening of bankruptcy proceedings for the purpose of restoring business operations of the corporate entities; Financial obligations toward the State; unsecured debts payable to the creditor in the credit list; secured debts not having been paid because of the insufficient value of the collateral; ways to repay the debts to each creditor in the list in case of insufficient value of the collateral...etc.... 


\section{Conclusion}

The new regulations on the criminal liability and criminal judgment execution against criminal corporate entities, especially specific provisions on the principles, subjects, measures, order and procedures of criminal judgment execution against corporate entities in Vietnam are still in the stage of formulation, and policy completion. From the initial research, we believe that although the new provisions on criminal judgment execution against corporate entities committing crimes in the Law on execution of criminal judgment 2019 include relatively reasonable developments, the most obvious shortcoming is the lack of a strategic criminal judgement execution policy applicable to corporate entities (which is different from the principles and measures applied to individual offenders). Therefore, in general, there is still a need for long-term overall and strategic studies, not just the ones to consider the reasonableness or the irrationality of each article applicable to the execution of criminal judgement against corporate entities.

\section{References}

1. D.D.H. Ha, Journal of Social Science Human Resources 5, 139-146 (2019)

2. D.T.Mai, Report, Corporate Criminal Liability, Hanoi Procecuration University (HPU) and Embassy of United States of America (Social Science Publishing House, 2019)

3. Đ.T. Mai, Journal of Social Science Human Resources, 5, 146-157 (2019)

4. Đ.T. Mai, Journal of Procuration Science, 13, $42-49$ (2019)

5. Ngo Duc Minh, Report, Seminar on "the execution of criminal judgments against corporate legal entities", Vietnam from February 28th to March 1st (2019)

6. Dau Anh Tuan, Report, Seminar on "the execution of criminal judgments against corporate legal entities", Vietnam from February 28th to March 1st (2019)

7. C. Fischer, Journal of Environmental Economics and Management, 38 (2002) DOI:

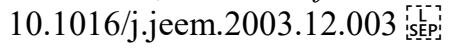

